ORIGINAL ARTICLE

\title{
Mice deleted for cell division cycle 73 gene develop parathyroid and uterine tumours: model for the hyperparathyroidism-jaw tumour syndrome
}

\author{
GV Walls ${ }^{1}$, M Stevenson ${ }^{1}$, KE Lines ${ }^{1}$, PJ Newey ${ }^{1}$, AAC Reed ${ }^{1}$, MR Bowl ${ }^{1}$, J Jeyabalan ${ }^{1}$, B Harding ${ }^{1}, \mathrm{KJ} \mathrm{Bradley}^{1}, \mathrm{~S} \mathrm{Manek}^{2}, \mathrm{~J} \mathrm{Chen}^{3}$, \\ P Wang ${ }^{3}$, BO Williams ${ }^{4}$, BT Teh ${ }^{3}$ and RV Thakker ${ }^{1}$
}

The hyperparathyroidism-jaw tumour (HPT-JT) syndrome is an autosomal dominant disorder characterized by occurrence of parathyroid tumours, often atypical adenomas and carcinomas, ossifying jaw fibromas, renal tumours and uterine benign and malignant neoplasms. HPT-JT is caused by mutations of the cell division cycle 73 (CDC73) gene, located on chromosome 1 q31.2 and encodes a 531 amino acid protein, parafibromin. To facilitate in vivo studies of Cdc73 in tumourigenesis we generated conventional $\left(C d c 73^{+/-}\right)$and conditional parathyroid-specific ( $C d c 73^{+/ L} / P T H-C r e$ and $\left.C d c 73^{L / L} / P T H-C r e\right)$ mouse models. Mice were aged to $18-21$ months and studied for survival, tumour development and proliferation, and serum biochemistry, and compared to age-matched

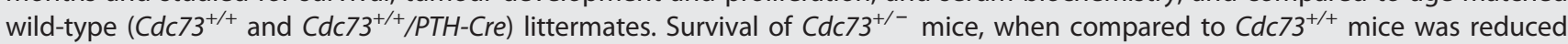

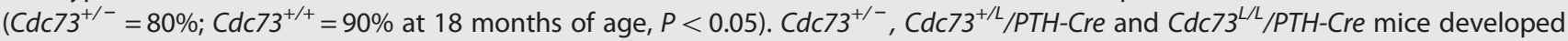
parathyroid tumours, which had nuclear pleomorphism, fibrous septation and increased galectin-3 expression, consistent with atypical parathyroid adenomas, from 9 months of age. Parathyroid tumours in $\mathrm{Cdc} 73^{+/-}, \mathrm{Cdc} 73^{+/ L} / \mathrm{PTH}-\mathrm{Cre}$ and $\mathrm{Cdc} 73^{\mathrm{L} / \mathrm{L}} / \mathrm{PTH}-\mathrm{Cre}$ mice had significantly increased proliferation, with rates $>$ fourfold higher than that in parathyroid glands of wild-type littermates

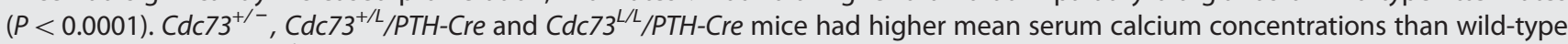
littermates, and $\mathrm{Cdc}_{\mathrm{C}} 3^{+/-}$mice also had increased mean serum parathyroid hormone (PTH) concentrations. Parathyroid tumour development, and elevations in serum calcium and PTH, were similar in males and females. Cdc73 ${ }^{+/-}$mice did not develop bone or renal tumours but female $C d c 73^{+/-}$mice, at 18 months of age, had uterine neoplasms comprising squamous metaplasia, adenofibroma and adenomyoma. Uterine neoplasms, myometria and jaw bones of $C \mathrm{dc} 73^{+/-}$mice had increased proliferation rates that were 2 -fold higher than in $C d c 73^{+/+}$mice $(P<0.05)$. Thus, our studies, which have established mouse models for parathyroid tumours and uterine neoplasms that develop in the HPT-JT syndrome, provide in vivo models for future studies of these tumours.

Oncogene (2017) 36, 4025-4036; doi:10.1038/onc.2017.43; published online 13 March 2017

\section{INTRODUCTION}

Mutations of the cell division cycle 73 (CDC73) gene (OMIM \#607393), which is located on chromosome 1q31.2 and encodes a 531 amino acid protein called parafibromin, are associated with hereditary and non-hereditary forms of parathyroid carcinomas and the hyperparathyroidism-jaw tumour (HPT-JT) syndrome (OMIM \#145001). ${ }^{1-3}$ HPT-JT, an autosomal dominant disorder, is characterized by the occurrence of parathyroid tumours, and ossifying fibromas of the jaw which occur in $\sim 30 \%$ of HPT-JT patients (Table 1)., ${ }^{1,4-6}$ The parathyroid tumours are usually parathyroid adenomas (PAs) but may be atypical parathyroid adenomas (APAs) or parathyroid carcinomas (PCs) in $>15 \%$ of HPT-JT patients. In addition, $>15 \%$ of HPT-JT patients may also develop renal tumours, which include Wilms' tumours, hamartomas and carcinomas, and $\sim 75 \%$ of women with HPT-JT will develop, at an early age, benign and malignant neoplasms of the uterus that may be associated with recurrent miscarriages and severe menorrhagia, requiring hysterectomy. ${ }^{4,5,7-9}$ These uterine neoplasms which all arise in cells derived from the embryonic mesodermal Mullerian duct system, comprise extensive adenomyosis, adenofibromas, endometrial hyperplasia, leiomyosis and adenosarcomas in $\sim 55 \%, \sim 35 \%, \sim 30 \%, \sim 30 \%$ and $\sim 15 \%$ of patients, respectively, and women with HPT-JT, may have more than one type of uterine neoplasm (Table 1). Other tumours that may arise in $<2 \%$ of HPT-JT patients are Hürthle cell thyroid adenomas, pancreatic adenocarcinomas and mixed germ cell testicular tumours. ${ }^{4,5,7,8}$ CDC73 loss of heterozygosity ( $\mathrm{LOH}$ ) has been observed in HPT-JT associated tumours, thereby indicating a likely tumour suppressor role for $C D C 73 .{ }^{1}$ A tumour suppressor role for $C D C 73$ is further supported by reports that the majority of CDC73 mutations are predicted to result in a functional loss of parafibromin, and that some HPT-JT tumours and non-hereditary PCs harbour both germline and somatic mutations, consistent with the Knudson 'two-hit' hypothesis. ${ }^{10-12}$

Parafibromin, which is encoded by exons 1-17 of CDC73 (Figure 1a), is a ubiquitously expressed predominantly nuclear protein that is evolutionary conserved. ${ }^{1}$ Moreover, the $\sim 200$ amino acids of the terminal segment of parafibromin have $\sim 27 \%$

\footnotetext{
${ }^{1}$ Academic Endocrine Unit, Oxford Centre for Diabetes, Endocrinology and Metabolism (OCDEM), Radcliffe Department of Medicine, University of Oxford, Churchill Hospital, Oxford, UK; ${ }^{2}$ Department of Pathology, John Radcliffe Hospital, Headley Way, Oxford, UK; ${ }^{3}$ Laboratory of Cancer Genetics, Van Andel Research Institute, Grand Rapids, MI, USA and ${ }^{4}$ Center for Cancer and Cell Biology, Van Andel Research Institute, Grand Rapids, MI, USA. Correspondence: Professor RV Thakker, Academic Endocrine Unit, Oxford Centre for Diabetes, Endocrinology and Metabolism (OCDEM), Radcliffe Department of Medicine, University of Oxford, Churchill Hospital, Oxford OX3 7LJ, UK Email: rajesh.thakker@ndm.ox.ac.uk

Received 18 August 2016; revised 22 December 2016; accepted 24 January 2017; published online 13 March 2017
} 
Table 1. Proportion of tumours (percent) in patients with the hyperparathyroidism-jaw tumour (HPT-JT) syndrome and $\mathrm{Cdc} 3^{+/-}$ mice

\begin{tabular}{|c|c|c|}
\hline Tumour & HPT-JT patients & $\begin{array}{l}\mathrm{Cdc} 73^{+/-} \text {mice } \\
(\geqslant 18 \text { months })\end{array}$ \\
\hline Parathyroid & $\begin{array}{l}82 \% \text { adenoma }(108 / 132)^{1} \\
>15 \% \text { carcinoma }(20 / 132)^{1,9}\end{array}$ & $\begin{array}{l}68 \% \text { overall } \\
25 \% \text { adenoma } \\
75 \% \text { atypical adenoma }\end{array}$ \\
\hline Mandible & $33 \%$ ossifying fibroma $(67 / 205)^{9}$ & $0 \%$ \\
\hline Uterus & $\begin{array}{l}74 \% \text { overall }(20 / 27)^{7,9} \\
53 \% \text { adenomyosis }(8 / 15) \\
33 \% \text { adenofibroma }(5 / 15)\end{array}$ & $\begin{array}{l}33 \% \text { overall } \\
100 \% \text { endometrial cysts } \\
25 \% \text { endometrial } \\
\text { hyperplasia }\end{array}$ \\
\hline & $27 \%$ endometrial hyperplasia $(4 / 15)$ & $13 \%$ adenofibroma \\
\hline & $\begin{array}{l}27 \% \text { leiomyoma }(4 / 15) \\
13 \% \text { adenosarcoma }(2 / 15)\end{array}$ & $13 \%$ adenomyoma \\
\hline Kidney & $\begin{array}{l}16 \% \text { hamartoma }(21 / 132)^{5} \\
<2 \% \text { Wilms' tumour }(3)^{4}\end{array}$ & $0 \%$ \\
\hline Thyroid & $\begin{array}{l}<2 \% \text { Papillary thyroid } \\
\text { carcinoma }(2)^{7} \\
<1 \% \text { Hurthle cell adenoma }(1)^{8}\end{array}$ & $0 \%$ \\
\hline Pancreas & $<1 \%$ Adenocarcinoma $(1)^{8}$ & $0 \%$ \\
\hline Testis & $<1 \%$ Mixed germ cell tumour $(1)^{8}$ & $0 \%$ \\
\hline
\end{tabular}

sequence identity and $47 \%$ similarity to the yeast Cdc73 protein, which is a component of the polymerase-associated factor-1 (Paf1) complex, ${ }^{13}$ a key transcriptional regulatory complex that interacts directly with RNA polymerase II. The crystal structure of the yeast Cdc73 C-domain has been reported to adopt a Ras-like fold that participates in histone ubiquitination and methylation steps through both promoter and coding regions, and studies have shown that human homologues of the yeast Paf1 complex are associated with parafibromin. ${ }^{14-16}$ Moreover, parafibromin and its Drosophila homologue, Hyrax, which is a component of the Wnt1 wingless pathway and has an essential role in normal embryonic development, have a high degree of sequence similarity in their C-terminal portions. ${ }^{17,18}$ This suggested that parafibromin may have a role in embryonic development and studies of mice deleted for $C d c 73$ have also shown that parafibromin has key roles in mammalian embryonic development. ${ }^{19}$ Thus, $C d c 73$ null mice were embryonic lethal by 6.5 day post-coitum, which is the stage when implantation occurs. ${ }^{19}$ Parafibromin and Hyrax also have a high degree of sequence similarity in their N-terminal domains, which directly interact with $\beta$-catenin/Armadillo in the context of the PAF1 complex. ${ }^{17}$ The role of parafibromin as a mediator of Wnt signalling is supported by studies in human HEK293 cells, which has shown that Wnt target gene expression is directly correlated with parafibromin expression. ${ }^{17}$ Moreover, parafibromin overexpression in HEK293 and NIH3T3 cells strongly inhibits proliferation, and in HeLa cells it increases G1 phase arrest and apoptosis with a concomitant reduction in S-phase entry, and a resulting downregulation of the cell cycle regulator cyclin D1, which is an oncogene known to be upregulated in parathyroid tumours. ${ }^{19-21}$ Furthermore, underexpression of parafibromin, induced by $\mathrm{RNAi}$, has been reported to increase the proportion of HeLa cells in S-phase, and to reduce basal apoptosis. ${ }^{13}$ These in vitro findings indicate that parafibromin is a likely tumour suppressor in mammalian cells, and to explore further the role of parafibromin as an in vivo tumour suppressor we studied mice deleted for Cdc73 for the development of tumours.

\section{RESULTS}

Generation, viability and survival of mice deleted for $\mathrm{Cdc73}$ alleles Conventional $C d c 73$ knockout mice were established using the embryonic stem (ES) cell line (RRE190) from Bay Genomics Genetrap resource (Figure 1a), ${ }^{22}$ as described, ${ }^{19}$ and congenic animals obtained by backcrossing onto wild-type C57BL/6 females for ten generations. Expression of wild-type and mutant Cdc73 and parafibromin, was detected by RT-PCR (Figure 1b) and western blot analysis (Figure 1c), respectively, to establish the wild-type $\left(\mathrm{Cdc}^{\mathrm{C}} \mathrm{3}^{+/+}\right)$and heterozygote $\left(\mathrm{Cdc} 73^{+/ G t(R R E 190) B y g}\right.$, referred to as $C \mathrm{Cc} 3^{+/-}$) genotypes of adult mice. $\mathrm{Cdc} 73^{+/-}$mice were viable and fertile and homozygote (Cdc73Gt(RRE190)Byg/Gt(RRE190)Byg, referred to as $\left(d c 73^{--}\right)$mice have been previously reported to demonstrate embryonic lethality. ${ }^{19}$ Kaplan-Meier analysis of 284 mice, comprising $104 C d c 73^{+/+}$mice ( $n=36$ male, 68 female) and $180 \mathrm{Cdc}^{+/-}$mice ( $n=72$ male, 108 female) aged to 18 months, revealed a significantly decreased survival of $\mathrm{Cdc}_{7} 3^{+/-}$mice compared to $\mathrm{Cdc73^{+/+ }}$ mice (survival of $\mathrm{Cdc73^{+/- }}$ versus $\mathrm{Cdc73^{+/+ }}$ mice $=80 \%$ versus $90 \%$, Figure $2 a, P<0.05$ ). Further analysis of this data by gender, revealed that the decreased survival of $\mathrm{Cdc} 73^{+/-}$mice was largely due to decreased survival of male $\mathrm{Cdc} 73^{+/-}$mice, which was observed from 7 months of age (Figure 2b); the survival of $C d c 73^{+/+}$male and female mice was similar (Figure 2c). The decreased survival in male $\mathrm{Cdc} 73^{+/-}$mice was not associated with lower bodyweight (Figure $2 \mathrm{~d}$ ), which was consistent with the reported mean bodyweight for C57BL/6 mice of similar ages. ${ }^{23}$

Parathyroid-specific Cdc73 conditional knockout mice, were generated by mating parathyroid hormone (PTH)-Cre transgenic mice ${ }^{24}$ with previously established $C d c 73$-floxed mice $\left(C d c 73^{L / L}\right) .{ }^{19}$ This resulted in mice deleted for one or both $C d c 73$ alleles in the parathyroids, that yielded heterozygote $C d c 73^{+/ L} / \mathrm{PTH}-\mathrm{Cre}$ and homozygote $C d c 73^{L / L} / P T H-C r e$ mice, respectively, ${ }^{19,24}$ which were viable and fertile. A total of 52 parathyroid-specific $C d c 73$ knockout mice were generated, and comprised $20 \mathrm{Cdc} 73^{+/+} / \mathrm{PTH}$-Cre mice, $15 \mathrm{Cdc73}+/ /$ PTH-Cre mice and $17 \mathrm{Cdc73}$ L/L/PTH-Cre mice.

\section{Examination for development of HPT-JT associated tumours.}

Development of HPT-JT associated tumours was assessed in 69 mice ( $21 \mathrm{Cdc} 3^{+/+}$mice (9 males and 12 females) and $48 \mathrm{Cdc} 73^{+/-}$ conventional knockout mice ( 12 males and 36 females)) between the ages of $>7$ to $<24$ months (Table 1). Parathyroid tumours were found to occur in $68 \%$ of $C d c 73^{+/-}$mice, and $25 \%$ of these were adenomas and $75 \%$ were APAs (defined by having collagenous fibrous septa, ${ }^{25}$ and/or immunostaining for galectin3 but lacking evidence of invasion or metastasis). We used immunostaining for galectin-3, which is an anti-apoptotic lectin that regulates cyclin D1 and C-Jun N-terminal kinase 1 (JNK1) expression and promotes tumour growth and metastasis, ${ }^{26,27}$ as it has been reported to have a sensitivity of $>95 \%$ and specificity of $90 \%$ for pathological diagnosis of PC in man. ${ }^{28,29}$ Uterine neoplasms were found in $\sim 33 \%$ of $\mathrm{Cdc}^{+/-}$females (Table 1). Parathyroid tumours or uterine neoplasms were not found to occur in $\mathrm{Cdc}_{\mathrm{C}} 3^{+/+}$mice. Ossifying fibromas of the jaw, and tumours of the kidneys, thyroid, pancreas or testis (Table 1) were not found in any of the $\mathrm{Cdc}_{\mathrm{C}} 3^{+/-}$or $\mathrm{Cdc73^{+/+ }}$ mice. Parathyroid tumour development was also found to occur in $>40 \%$ of the 32 conditional knockout mice, which comprised $15 \mathrm{Cdc} 73^{+/ L} / \mathrm{PTH}-\mathrm{Cre}$ mice ( 9 males and 6 females) and $17 \mathrm{Cdc} 73^{L / L} / \mathrm{PTH}$-Cre mice ( 8 males and 9 females), but not in any of $20 \mathrm{Cdc} 73^{+/+} / \mathrm{PTH}$-Cre mice (11 males and 9 females), aged 20-21 months of age. The parathyroid and uterine neoplasms developing in the mutant mice were further studied.

Analysis of parathyroid tumours

Parathyroid glands were identified in $74 \%$ of mice $(n=109)$ and the remaining $26 \%$ of mice in whom parathyroid glands were not identified were evenly distributed among all the genotypes. Parathyroid tumours were found in $>65 \%$ of $\mathrm{Cdc}_{3} 3^{+/-}$mice $(n=15 / 22)$ but in none of $16 C d c 73^{+/+}$littermates $(P<0.0001$, twotailed Fisher's exact test, Table 1), between 9 and 18 months of age; and in $\geqslant 50 \%$ of $\geqslant 18$-month-old Cdc $73^{+/ L} /$ PTH-Cre $(n=7 / 12)$ 




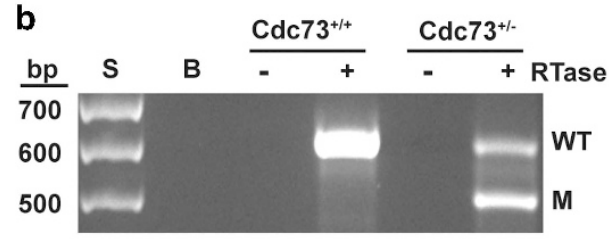

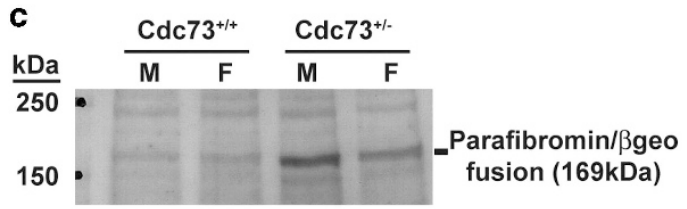

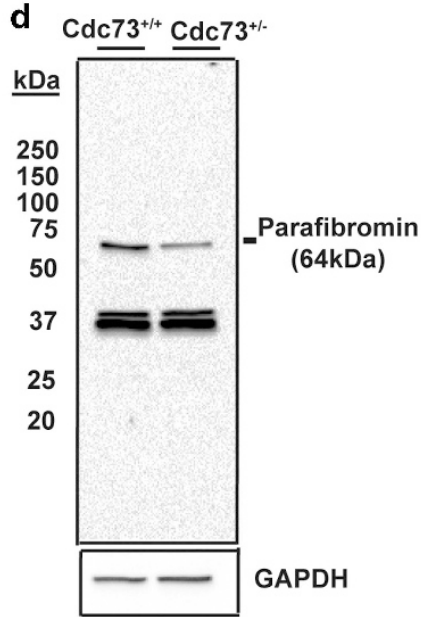

Figure 1. Establishing a conventional Cdc73 knockout mouse model. (a) Schematic diagram of the Cdc73 gene representing the wild-type (WT, $+)$ and recombinant $(\mathrm{R},-)$ alleles. ATG and TGA represent the start and stop codons respectively. The exons are represented by boxes (open boxes depict translated regions), and the domains within the GeneTrap (Gt) vector, incorporated into the R allele, are labelled. The GeneTrap vector in the RRE190 ES cells from BayGenomics ${ }^{22}$ referred to as $\mathrm{Gt}^{(\mathrm{RRE} 190 \mathrm{Byg})}$ is inserted into intron 6 of the Cdc73 gene and subsumes normal splicing of the $C d c 73$ exon 6 donor site to the GeneTrap Engrailed2 (EN2) acceptor site with loss of exons 7-17. Thus, the parafibromin- $\beta$-geo fusion from the first six exons of the $C d c 73$ gene, would contain only the N-terminal 170 amino acids, which encompasses the nuclear localization signal, and lack the remaining 361 amino acids which will encompass the domains that interact with the Paf1 complex, histone methyltransferase complexes, ${ }^{16}$ and $\beta$-catenin,${ }^{17}$ of the wild-type parafibromin. A loss of these critical domains would render the expressed mutant parafibromin non-functional. LoxP (locus of crossing over in phage P1), Lox71 (locus of crossing over 71), FRT (flippase recognition target), SA (splice acceptor of mouse), $\beta G e o$ (EN2 exon 2, fusion of $\beta$-galactosidase and neomycin transferase), IRES (internal ribosome entry site), PLAP (placental alkaline phosphatase) and SV4OpA (Simian virus 40 polyadenylation signal). The Lox71, LoxP and FRT sites, located in the GeneTrap vector allow the capability to remove the engrailed intron and $\beta$-geo, by breeding with Cre or Flp expressing mice, in order to restore gene function. However, this was not undertaken for this study. (b) Identification of wild-type $\left(C d c 73^{++}\right)$and heterozygous $\left(C d c 73^{+/-}\right)$ mice by RT-PCR using template RNA extracted from kidneys of adult mice and primers ( $3 \mathrm{f}$, $9 \mathrm{r}$ and rev). The sizes of the wild-type (WT) and mutant (M) bands are 593 and $500 \mathrm{bp}$, respectively. (c) Western blot analysis of kidney lysates from adult $C d c 73^{+/+}$and $C d c 73^{+/-}$mice, utilizing an anti- $\beta$-geo antibody, revealed the expression of a parafibromin/beta-geo fusion protein (169 $\mathrm{kDa})$ in $\mathrm{Cdc} 73^{+-} \mathrm{knockout} \mathrm{mice} \mathrm{only.}$ (d) Analysis of parafibromin expression ( $64 \mathrm{kDa}$ ) using an anti-parafibromin antibody (A300-171A) revealed a $50 \%$ reduction in expression assessed by densitometry of band intensity normalized for GAPDH expression $(n=4)$ in $C d c 73^{+/-}$mice compared to $C d c 73^{+/+}$mice; the whole Western blot is shown. The specificity of the anti-parafibromin antibody was validated in HeLa cells transfected with siRNA against CDC73 (Supplementary Figure 1). These results also show that only one form of parafibromin of size $64 \mathrm{kDa}$ and representing the 531 amino acid protein is expressed by $C d c 73$, despite the reports of of 6 Cdc73 transcripts in the Ensembl database. ${ }^{75}$ These 6 murine $C d c 73$ transcripts comprise: transcript 1 which is 11586 bp and encodes a 531 amino acid protein; transcripts 2, 4, 5 and 6 which are 3134 bp, 3056 bp, 2727 bp and $1047 \mathrm{bp}$, respectively, in length and are processed transcripts or retained introns that do not lead to protein products; and transcript 3 that is $479 \mathrm{bp}$ in length and results in a 73 amino acid protein and subject to nonsense mediated decay. Thus, the observation of only one form of parafibromin of $64 \mathrm{kDa}$, is consistent with the translation of transcript 1 in the Ensembl database, ${ }^{75}$ wich results in the 531 amino acid parafibromin. The $37 \mathrm{kDa}$ bands, which do not correspond to any translated proteins from the other transcripts, are present with similar intensities in $C d c 73^{+/-}$and $C d c 73^{+/+}$mice $(P=0.493, n=4)$, and are likely to represent non-specific bands. Such non-specific bands, which were not altered by the use of CDC73 siRNA (siCDC73), were also detected in HeLa cells (Supplementary Figure 1). B, blank; F, female; M, male; RTase, reverse transcriptase; $\mathrm{S}$, size marker.

and $C d c 73^{L / L} / P T H-C r e(n=6 / 12)$ mice, but not in any of 19 $\mathrm{Cdc} 73^{+/+} /$PTH-Cre littermates $(P<0.005)$. The parathyroids in wild-type mice were $\sim 500 \mu \mathrm{m}$ in length (Supplementary Figure 2) and had a homogenous appearance (Figure 3a). Parathyroid tumours (Figures $3 \mathrm{~b}-\mathrm{d}$ ), which were $\sim 1 \mathrm{~mm}$ in length (Supplementary Figure 2) and had a heterogenous architecture, developed in $C d c 73^{+/-}$, and $C d c 73^{+/ L} / P T H-C r e$ and $C d c 73^{L / L} / P T H-$ Cre mice, and these demonstrated abnormalities that included glandular enlargement, nuclear pleomorphism, and septation (Figures $3 b-d$ ), which are features often observed in PCs and APAs. Indeed $75 \%$ of the parathyroid tumours of $\mathrm{Cdc}_{3} 3^{+/-}$, $C d c 73^{+/ L} / P T H-C r e$ and $C d c 73^{L / L} / P T H-C r e$ mice, when compared to wild-type littermates had features found in APAs (Table 1), ${ }^{1,9}$ that included: increased collagen deposition in the septa (Figures $3 e-$ h); reduced nuclear expression of parafibromin (Figures $3 \mathrm{i}-\mathrm{l}$ ); and increased expression of galectin-3 (Figures $3 m-p$ ). Loss of 
retinoblastoma protein expression and increased cyclin D1 expression, which are found in $>95 \%$ and $90 \%{ }^{30}$ of human PCs, respectively, were not found to occur in the parathyroid tumours from $\mathrm{Cdc} 73^{+/-}, \mathrm{Cdc} 73^{+/ L} / \mathrm{PTH}$-Cre and $\mathrm{Cdc} 73^{L / L} / \mathrm{PTH}$-Cre mice (data
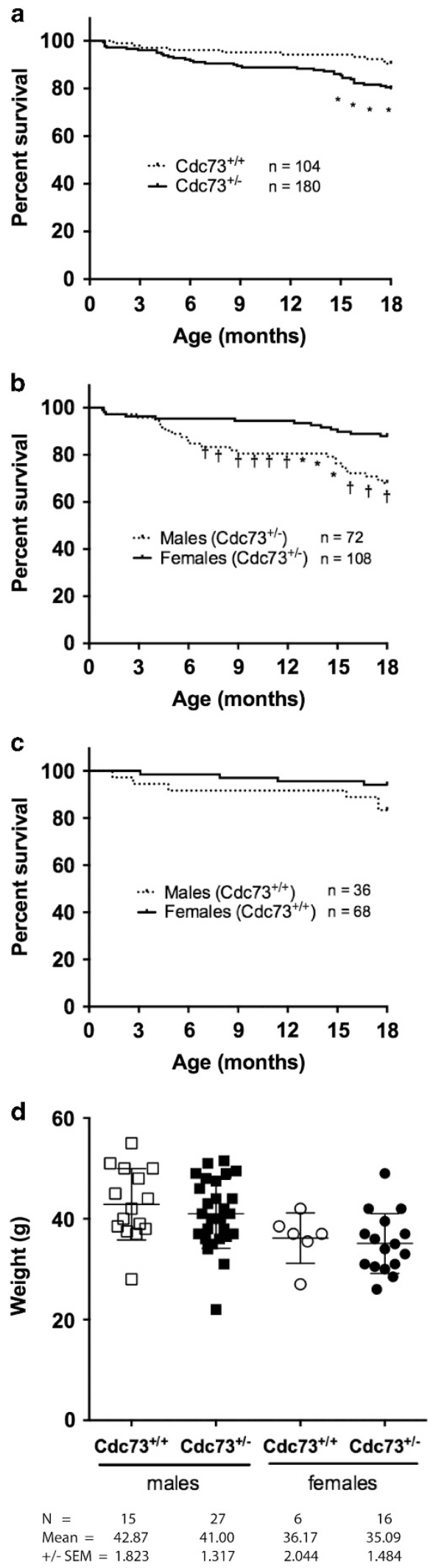

not shown). To assess the proliferation rate of these parathyroid tumours, mice were given the thymidine analogue BrdU in drinking water for two weeks, ${ }^{31}$ and the proportion of cells that had incorporated nuclear BrdU was calculated (Figures $3 q-t$, Table 2). The parathyroid tumours developing in the $\mathrm{Cdc} 73^{+/-}$and $\mathrm{Cdc} 73^{+/ L} / \mathrm{PTH}$-Cre mice had significantly higher daily proliferation

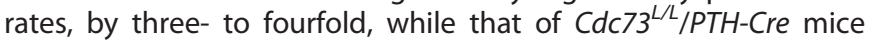
was $\sim 9$-fold higher, when compared to those of parathyroid glands in wild-type mice $C d c 73^{+/+}$and $C d c 73^{+/+} / P T H-C r e$ mice (Table 2, $P<0.0001$ ). Apoptotic rates in parathyroids of $C d c 73^{+/-}$, $\mathrm{Cdc} 73^{+/ L} / \mathrm{PTH}-\mathrm{Cre}$ and $\mathrm{Cdc73} / \mathrm{L} / \mathrm{PTH}-\mathrm{Cre}$ mice were not significantly different from wild-type $\left(C d c 73^{+/+}\right.$and $C d c 73^{+/+} / P T H$-Cre $)$ littermates (Figures 3u-x, Supplementary Figure 4).

Parathyroid tumours in the $C d c 73^{+/-}(n=25$, age $>17$ months), when compared to similarly aged wild-type $C d c 73^{+/+}$littermates $(n=20)$, were associated with increased mean ( \pm s.e.m.) serum calcium concentrations $\left(C d c 73^{+/-}\right.$versus $C d c 73^{+/+}=2.85 \pm 0.04 \mathrm{mmol} / \mathrm{l}$ versus $2.66 \pm 0.08 \mathrm{mmol} / \mathrm{l}, P<0.05$, Figure $4 \mathrm{a}$ ), that was accompanied by a significantly increased mean ( \pm s.e.m.) serum parathyroid hormone (PTH) concentration $\left(\mathrm{Cdc} 3^{+/-}\right.$versus $C d c 73^{+/+}=81.34 \pm 10.29 \mathrm{pmol} / \mathrm{l}$, versus $52.03 \pm 7.43 \mathrm{pmol} / \mathrm{l}, P<0.05$, Figure $4 b$ ). The serum phosphate (Figure 4c), creatinine (data not shown) and albumin concentrations (data not shown) were not statistically different between $\mathrm{Cdc} 73^{+/-}$and $\mathrm{Cdc} 73^{+/+}$mice aged 17-24 months, and $\mathrm{Cdc}_{3} 3^{+/-}$and $C \mathrm{Cdc} 3^{+/+}$mice $\leqslant 12$ months of age had no statistical differences in serum calcium, adjusted for albumin, or serum phosphate concentrations (data not shown). Thus, $C d c 73^{+/-}$mice over 17 months of age had features of primary hyperparathyroidism. $C d c 73^{+/ L} /$ PTH-Cre $(n=5$, age $>20$ months) and Cdc73//LPTH-Cre ( $n=5$, age $>20$ months) mice, when compared to $C d c 73^{+/+} / \mathrm{PTH}$-Cre $(n=9)$ littermates also had elevated mean $\left( \pm\right.$ SEM) serum calcium concentrations $\left(C d c 73^{+/ L} /\right.$ PTH-Cre $=2.81 \pm 0.07 \mathrm{mmol} / \mathrm{l}, \quad C d c 73^{L / L} / \mathrm{PTH}$-Cre $2.76 \pm 0.08 \mathrm{mmol} / \mathrm{I}$ and $\left.\mathrm{Cdc}_{3} 3^{+/} / \mathrm{PTH}-\mathrm{Cre}=2.52 \pm 0.07 \mathrm{mmol} / \mathrm{l}, P<0.01\right)$. The serum albumin (data not shown), creatinine (data not shown) and phosphate concentrations were not significantly different $\left(C d c 73^{+/ L}\right.$ / PTH-Cre $=3.27 \pm 0.13 \mathrm{mmol} / \mathrm{l}, \mathrm{Cdc} 73^{\mathrm{L} / \mathrm{L}} / \mathrm{PTH}-\mathrm{Cre}=3.37 \pm 0.40 \mathrm{mmol} / \mathrm{l}$ and $\left.\mathrm{Cdc} 73^{+/+} / \mathrm{PTH}-\mathrm{Cre}=2.99 \pm 0.23 \mathrm{mmol} / \mathrm{l}\right)$.

Analysis of uterine neoplasms

Macroscopic uterine tumours at necropsy were observed in $33.3 \%$ ( $n=8 / 24$ ) of female $C d c 73^{+/-}$mice, aged $\geqslant 18$ months, but in none of $24 \mathrm{Cdc}^{+/++}$littermates $(P<0.005$, two-tailed Fisher's exact test). Histology of $\geqslant 18$ month old $C \mathrm{Cdc}^{+/-}$mice demonstrated several abnormalities, when compared to those from $\mathrm{Cdc} 73^{+/+}$ littermates (Figures 5a-e). Thus, uteri from $C d c 73^{+/+}$mice had glandular endometria with a uniform mucosal epithelium, whereas uteri from $C \mathrm{Cc}_{\mathrm{C}} 3^{+/-}$mice had: large cysts within the

Figure 2. Survival and weights of $C d c 73^{+/+}$and conventional $C d c 73^{+/}$ - knockout mice. (a) Survival of $C d c 73^{+/+}$and $C d c 73^{+/-}$mice (data for male and female mice combined) over 18 months. Kaplan-Meier analysis revealed significantly lower survival in $\mathrm{Cdc} 73^{+/-}$mice when compared to $\mathrm{Cdc}_{7} 3^{+/+}$mice (80 versus $90 \%$, Log-rank Mantel Cox test, $P<0.05)$. Moreover the reduced survival in the $\mathrm{Cdc73^{+/- }}$ mice was observed from 15 months of age ( ${ }^{*} P<0.05$, Fisher's exact test). (b) Kaplan-Meier analysis showed that $C d c 73^{+-}$males had significantly reduced survival than $\mathrm{Cdc}_{\mathrm{C}} 3^{+/-}$females (Log-rank Mantel Cox test, $P<0.005$ ), which was observed from the age of 7 months $\left({ }^{*} P<0.05,{ }^{\dagger} P<0.01\right.$, Fisher's exact test). (c) Kaplan-Meier analysis showing that survival of male and female $C d c 73^{+++}$mice was similar. Moreover, the survival of $C d c 73^{+/+}$male mice did not differ significantly $(P=0.094)$ from that of $C d c 73^{+/-}$male mice (see above). (d) Bodyweights at 18 months of age of $\mathrm{Cdc} 73^{+/+}$and $\mathrm{Cdc} 73^{+/-}$mice, showing that the mean bodyweights of $\mathrm{Cdc} 73^{+/+}$and $\mathrm{Cdc} 73^{+/-}$ males, and of $\mathrm{Cdc}_{\mathrm{C}} 3^{+/+}$and $\mathrm{Cdc7} 3^{+/-}$females were similar. 
endometrium (Figures 5b-e); endometrial hyperplasia with areas of squamous metaplasia (Figures $5 \mathrm{~b}-\mathrm{c}$ ); and bridging of the endometrial lining across the uterine lumen (Figures $5 \mathrm{~b}-\mathrm{e}$ ). Furthermore, $\mathrm{Cdc}_{\mathrm{C}} 3^{+/-}$mice had uterine tumours which included an adenofibroma (Figure 5d) and an adenomyoma (Figure 5e), that were not observed in $\mathrm{Cdc} 73^{+/+}$littermates. Parafibromin expression was present in uteri of $\geqslant 18$ month old $C d c 73^{+/+}$mice (Figure $5 f$ ), but was reduced in uterine tumours (for example, fibroadenoma, Figure $5 \mathrm{~g}$ ) of $\mathrm{Cdc} 73^{+/-}$mice. Moreover assessment of progesterone receptor expression, which is a favourable prognostic marker in uterine tumours, ${ }^{32-35}$ revealed strong endometrial expression of progesterone receptor in uteri of $C d c 73^{+/+}$mice (Figure $5 \mathrm{~h}$ ), but absent endometrial progesterone receptor expression in all of the hyperplastic, fibroadenoma and adenomyoma lesions from $C d c 73^{+/-}$mice (Figure 5i), which instead had increased stromal expression of progesterone receptor.

Assessment of proliferation rates, using BrdU incorporation, revealed the myometria from $C d c 73^{+/-}$mice to have a $\sim 2$-fold increase in proliferation rates when compared to that of wild-type littermates (Table 2, $P<0.05$ ). This was confirmed by immunostaining for Ki-67, which revealed a significantly increased proliferation in the endometria and myometria of $\mathrm{Cdc}_{3} 3^{+/-}$mice with uterine tumours, by 1.5 - and 2.5 -fold, respectively, when compared to equivalent uterine tissues of wild-type littermates (Figures $5 \mathrm{j}-\mathrm{l}$ ).

\section{Other tumours}

Tumours of the bones, kidneys, thyroid, pancreas, or testes, which may develop in HPT-JT patients, were not detected macroscopically or microscopically in $\mathrm{Cdc73^{+/- }}$ mice, aged up to 21 months of age. Jaw bones of $\mathrm{Cdc73^{+/- }}$ mice had 2 -fold increased proliferation rates compared to wild-type littermates (Table $2, P<0.05$ ), but renal and pancreatic proliferation rates were similar in $C d c 73^{+/-}$ and wild-type littermates (Table 2).

\section{DISCUSSION}

The results of our study, which established mice deleted for $C d c 73$ alleles, reveal that these mice are representative of HPT-JT in man. Thus, $C d c 73^{+/-}$mice develop: parathyroid tumours in association with increased mean serum calcium concentrations and increased mean serum PTH concentrations, consistent with primary hyperparathyroidism; and uterine neoplasms, which comprised endometrial hyperplasia and cysts, adenofibroma and adenomyoma. Moreover, $75 \%$ of the parathyroid tumours were APAs, and thus these $\mathrm{Cdc73} 3^{+/-}$mice with the conditional $\mathrm{Cdc73} 3^{+/ L} / \mathrm{PTH}$ Cre and $C d c 73^{L / L} / P T H-C r e$ mice provide important in vivo models for this rare but difficult to treat human neoplasm. These parathyroid tumours and uterine neoplasms had a lack (or reduction) of nuclear expresison of parafibromin, consistent with a tumour suppressor role for $C d c 73$, and similar to the findings reported in HPT-JT associated tumours in man. ${ }^{36}$ However, there are some differences in the frequency of tumours that develop in the $C d c 73^{+/-}$mice and patients with HPT-JT, and five of these are as follows: (1) PAs are the commonest manifestation occuring in $>80 \%$ of HPT-JT patients, whereas they occurred in only $25 \%$ of $\mathrm{Cdc} 3^{+/-}$mice, the majority of which instead had APAs with features similar to PCs that occur in $\sim 15 \%$ of HPT-JT patients (Table 1); (2) ossifying jaw fibromas occur in $\sim 33 \%$ of HPT-JT patients, but were not found in $C d c 73^{+/-}$mice, which did however have an increased mandibular cell proliferation rate; (3) uterine adenomyosis and adenofibroma which are the commonest manifestations, occurring in 53\% and $33 \%$ of women with HPT-JT respectively, were rare (or not found) in $\mathrm{Cdc} 73^{+/-}$mice, which instead had endometrial cysts that were not observed in women with HPT-JT; (4) renal hamartomas and Wilm's tumour, which occur in $>15 \%$ and $<2 \%$ of HPT-JT patients, were not found in $\mathrm{Cdc}_{3} 3^{+/-}$mice; and (5) thyroid cancer, pancreatic adenocarcinoma and testicular germ cell tumours, which occur in $<2 \%$ of HPT-JT patients, were not found in $\mathrm{Cdc} 73^{+/-}$mice. The basis of these inter-species differences remain to be defined but they may be partly due to: the methods of detection, which may have missed detecting the small tumours in the $\mathrm{Cdc} 73^{+/-}$mice; the possible later onset of tumours, as suggested by the finding of the increased mandibular cell proliferation rate which may represent a pre-malignant or early neoplastic phase of tumourigenesis; the possible functional redundancy of parafibromin for tumourigenesis in kidneys, pancreas, testes and jaw of mice; and the effects of species-specific genetic modifiers that might alter the phenotypic expression of the $\mathrm{Cdc} 73$ mutation in a species. However, it is important to note that the $\mathrm{Cdc} 73^{+/-}$mice developed two of the most common tumours, namely parathyroid tumours and uterine neoplasms that are observed in HPT-JT patients. Thus, $C d c 73^{+/-}$mice provide an in vivo model for the study of APAs and uterine neoplasms. The development of these tumours resulted in $C d c 73^{+/-}$mice having a reduced survival (Figure 2a). Moreover, survival of $C d c 73^{+/-}$males was significantly less than $\mathrm{Cdc73}^{+/-}$females (Figure $2 \mathrm{~b}$ ), even though there were no differences in mean serum calcium or PTH concentrations, or the development of parathyroid tumours, between the genders. The basis of the decreased survival in $C d c 73^{+/-}$males remains unknown, but a reduction in signalling via insulin-like growth factor-1 (IGF-1), which is reported to favour female longevity in mice, ${ }^{37,38}$ may be contributing, especially as parafibromin in murine embryonic fibroblasts has been reported to bind the IGF-1 promoter, and the loss of parafibromin has been observed to decrease expression of $/ g f-1 .{ }^{19}$ Finally, our results, which demonstrate that both conventional $\left(\mathrm{Cdc}_{\mathrm{C}} 3^{+/-}\right)$and conditional

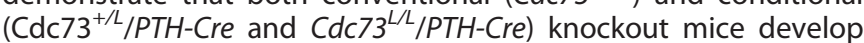
parathyroid tumours, indicate that $C d c 73$ has a critical role in parathyroid tumourigenesis.

PCs, which have an incidence from $0.5 \%$ to $5 \%$ of primary hyperparathyroidism cases, may metastasize to regional lymph nodes or distant sites such as lungs, liver, bone or pancreas, and patients will generally die from complications of the associated hypercalcaemia. ${ }^{39}$ The only curative treatment for PC is en bloc resection of the primary tumour. ${ }^{3}$ However, PC cannot be easily distinguished from APA or PA pre-operatively or intra-operatively, in the absence of macroscopic tumour invasion or metastasis, and thus most patients with PC do not receive curative surgery and require long-term medical management. ${ }^{39}$ Medical therapies, including chemotherapy and radiotherapy, are ineffective with the exception of cinacalcet, an allosteric modulator of the calcium-sensing receptor, which is effective in correcting the hypercalcaemia. ${ }^{39}$ Thus, improved medical therapies for PC are required. Parafibromin immunostaining may represent an important prognostic marker, as loss of parafibromin immunostaining has been reported to be associated with decreased disease-free survival and tumour recurrence in patients with PCs. ${ }^{40,41}$ Moreover, APAs with loss of parafibromin immunostaining are considered tumours of uncertain malignant potential as their recurrence rate is higher at $20 \%$ when compared to a $0 \%$ recurrence rate in APAs that express parafibromin. ${ }^{40,41}$ Thus, our conventional and conditional $C d c 73$ knockout mouse models that develop APAs lacking parafibromin expression will facilitate studies aimed at understanding the molecular pathogenesis of APAs, PCs and PAs, and in providing pre-clinical models for evaluating drugs.

CDC73 mutations occur in $\sim 70 \%$ of patients with sporadic, nonsyndromic PCs, and in $>75 \%$ of patients with HPT-JT. Indeed, CDC73 abnormalities, either due to mutations or LOH are the major driver for PCs in humans, although expression of a mutated parafibromin protein rather than complete loss of parafibromin expression has also been reported in some PCs. ${ }^{2}$ In addition copy number gain of mutant $C D C 73$ alleles, with loss of the wild-type 
4030

CDC73 allele through focal deletion or loss of the chromosomal arm have also been reported, ${ }^{42}$ and the roles and mechanims of such selections of mutated CDC73 alleles in parathyroid tumourigenesis remains to be elucidated. Mutations involving other genes are rare, and to date 6 multiple endocrine neoplasia type 1 (MEN1) germline mutations and 2 rearranged during transfection (RET) germline mutations have been reported in patients with PCs occurring in association with MEN1 and MEN2A, respectively; ${ }^{43-45}$
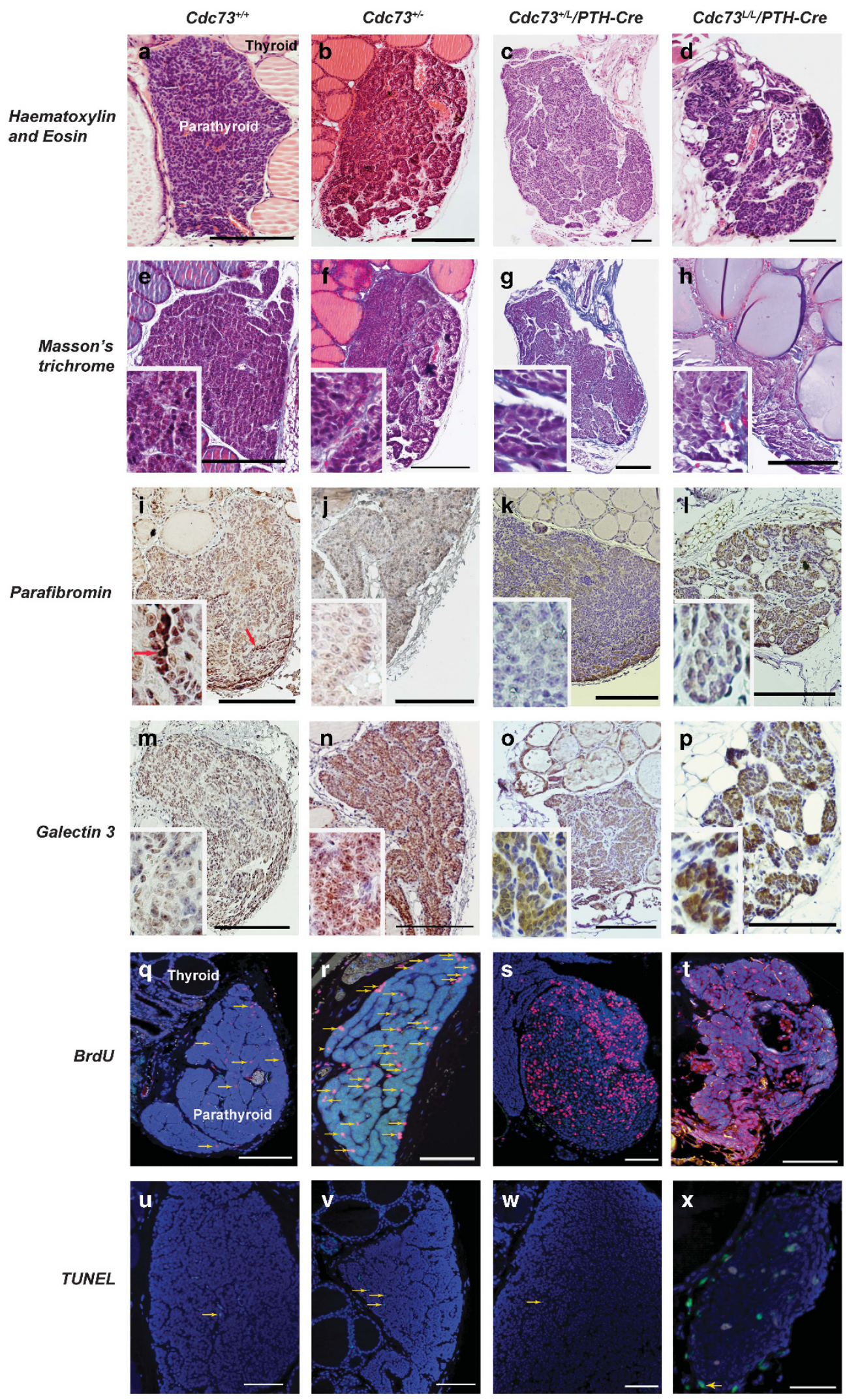
and 5 Prune Homolog 2 (PRUNE2) mutations (1 germline and 4 somatic) have been reported in PCs. ${ }^{42}$ Other genetic abnormalities that have been detected in human PCs include: retinoblastoma $(R B)$ loss of heterozygocity (LOH) and loss of expression (LOE) in $>85 \%$ of $\mathrm{PCs}^{4}{ }^{46}$ cyclin D1 (CCND1) overexpression in $>90 \%$ of $\mathrm{PCs}^{30}$ adenomatous polyposis coli (APC) LOH and LOE in $~ 75 \%$ of PCs; ${ }^{47}$ tumour protein 53 (TP53) LOH and LOE in $33 \%$ of PCs; glycogen synthase kinase $3-\beta$ (GSK3 $\beta$ ) LOE in $33 \%$ of $P C s ;{ }^{47}$ and enhancer of zeste homolog $2(E Z H 2)$ gene amplification in $60 \%$ of PCs. ${ }^{49}$ Abnormalities of these genes are not necessarily associated with PCs in mice. For example Men $1^{+/-}$mice develop PAs but not carcinomas; ${ }^{50}$ transgenic mice overexpressing cyclin D1 develop adenomas but not carcinomas; ${ }^{51} \mathrm{Rb}^{+/-}$mice develop medullary thyroid carcinomas and pituitary adenocarcinomas but not $\mathrm{PCs} ;{ }^{52}$ and $M e n 1^{+/-} / R^{+/-}$mice developed pituitary, thyroid and pancreatic islet hyperplasia, but not PCs. ${ }^{52}$ These findings indicate that loss of RB expression and increase of cyclin D1 expression may not be required for PC development in the mouse, and are consistent with our observations that RB and cyclin D1 expression were not altered in the APAs of $C d c 73^{+/-}$mice. Moreover, these finding indicate that $C d c 73$ abnormalities represent the major driver for PCs in humans and APAs in mice.

Uterine corpus tumours, are common, occurring in $>30 \%$ of women $>40$ years, and may be benign or malignant. ${ }^{53}$ Uterine tumours may originate from: the epithelial layer for example, endometrial hyperplasia or carcinoma; the mesenchymal layers,

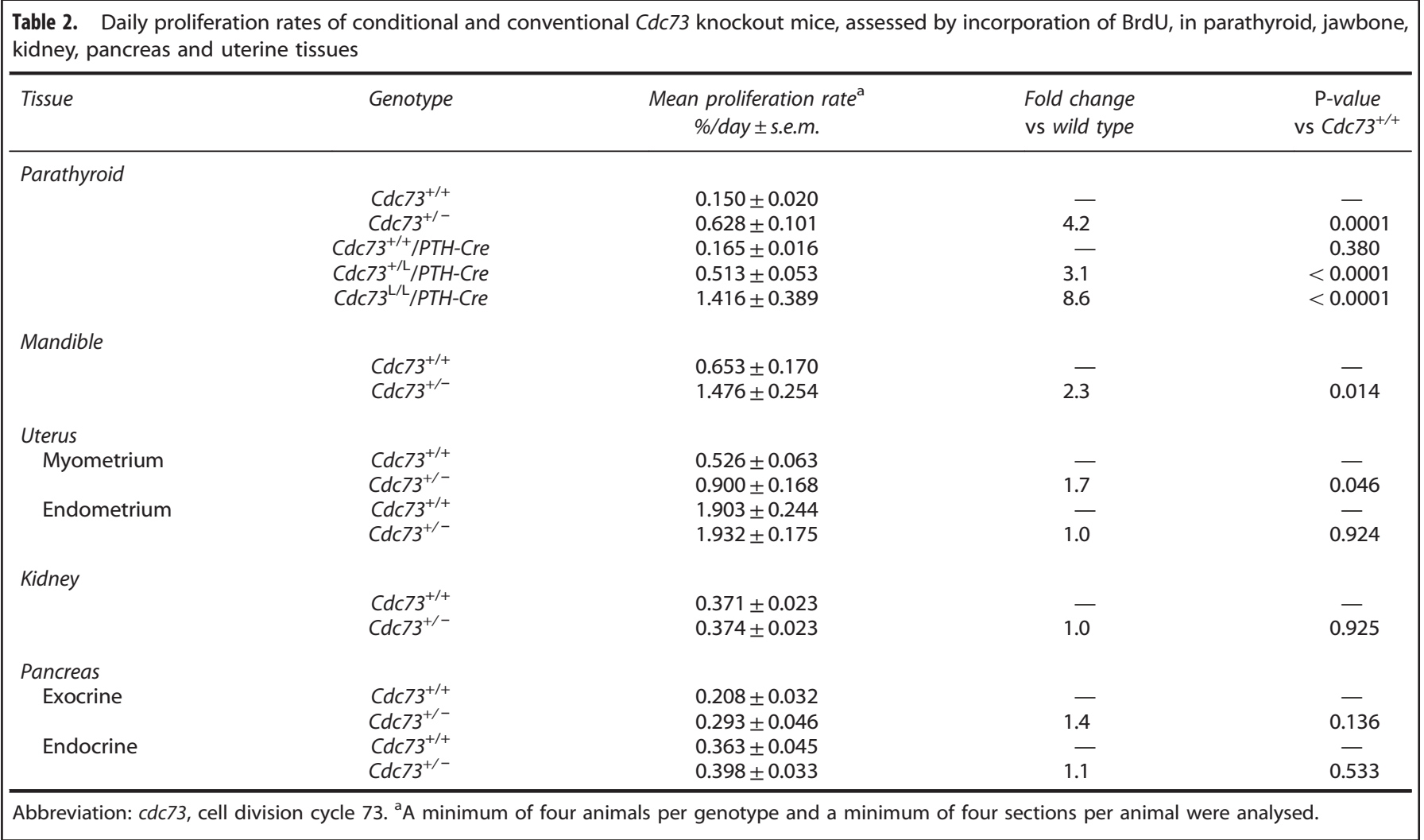

Figure 3. Parathyroid tumours develop in $\mathrm{Cdc73} 3^{+/-}$and parathyroid-specific $\mathrm{Cdc} 73^{+/ L} / \mathrm{PTH}-\mathrm{Cre}$ and $\mathrm{Cdc} 73^{L / L} / \mathrm{PTH}-\mathrm{Cre}$ knockout mice. (a-d) H\&Estained sections of parathyroid glands from wild-type $\left(C d c 73^{+/+}\right)$, heterozygote $\left(C d c 73^{+/-}\right.$and $\left.C d c 73^{+/ L} / P T H-C r e\right)$, and homozygote $\left(C d c 73^{L / L} /\right.$ PTH-Cre) mice, showing: (a) homogenous histology of a wild-type parathyroid; (b) enlarged PA from a Cdc73 ${ }^{+/-}$mouse; (c) a large PA from a $C d c 73^{+L /} / P T H-C r e ~ m o u s e$, with increased septation and irregular outline; and (d) abnormal architecture of a parathyroid gland from a Cdc $73^{L / L} /$ PTH-Cre mouse, with increased lipid deposition, nodularity, necrosis and septation. (E-H) Masson's trichrome stained sections of parathyroids of

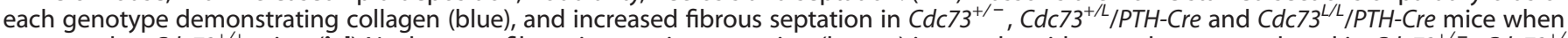
compared to $C d c 73^{+/+}$mice. (i-I) Nuclear parafibromin protein expression (brown) in parathyroids was absent or reduced in $C d c 73^{+/-}, C d c 73^{+/}$ $\mathrm{L} / \mathrm{PTH}$-Cre and $\mathrm{Cdc} 73^{\mathrm{L} / \mathrm{L}} / \mathrm{PTH}$-Cre mice (j-I), when compared to $\mathrm{Cdc} 73^{+/+}$mice (i) (a cluster of parafibromin expressing cells is indicated by the red arrow in panel and inset). Importantly, nuclear parafibromin expression was not reduced in pancreatic exocrine and exocrine cells, endothelial cells and thyroid epithelial cells of $C d c 73^{+/ L} / P T H-C r e$ and $C d c 73^{L / L} / P T H-C r e$ mice, thereby confirming the parathyroid-specific loss of $C d c 73$ expression resulting from the presence of PTH-Cre (Supplementary Figure 3). ( $\mathbf{m}-\mathbf{p})$ Galectin-3 protein expression (brown cytoplasm) in parathyroids was increased in $C d c 73^{+/-}, C d c 73^{+/ L} / P T H-C r e$ and $C d c 73^{L / L} / P T H-C r e$ mice (n-p), when compared to Cdc73 $3^{+/+}$mice (m). (q-t) Assessment of parathyroid tumour proliferation by immunofluorescent BrdU incorporation, by continuous administration of BrdU in drinking water, showing that: (q) few parathyroid cells had proliferated in $C d c 73^{+/+}$mice; but that ( $\mathbf{r}$-t) higher proportions of parathyroid cell nuclei had

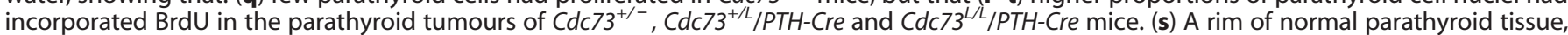
to the left of the image, had low proliferation, whilst the tumour nodule demonstrated focal areas with a high proportion of nuclei that had incorporated BrdU. BrdU-containing nuclei (red, arrows) indicate cellular proliferation; DAPI nuclear counterstain (blue). (u-x) Assessment of apoptosis by TUNEL assay. Apoptotic cells (green nuclei, arrows) were infrequently observed in parathyroids from mice of each genotype; DAPI nuclear counterstain (blue). Scale bars represent $200 \mu \mathrm{m}$; insets have $\mathrm{x} 400$ magnification. 
for example, leiomyomas (uterine fibroids), which are benign smooth muscle tumours that develop in the myometrium; or both (that is, mixed epithelial and mesenchymal) layers, for example, carcinosarcomas which have malignant epithelial and mesenchymal components, and adenosarcomas which are neoplasms composed of benign epithelium but malignant stroma. ${ }^{54-57}$ The uterine tumours that develop in women with HPT-JT include benign tumours such as endometrial hyperplasia, adenomyosis, adenofibromas and leiomyosis, and malignant tumours, such as adenosarcomas. ${ }^{13,14} \mathrm{Cdc} 73^{+/-}$female mice devloped uterine tumours, that were representative of those in women with HPTJT and these included endometrial hyperplasia, adenomyoma and adenofibroma. These uterine neoplasms developed in $~ 33 \%$ of female $\mathrm{Cdc73}^{+/-}$mice (Figure 5), whilst spontaneous uterine lesions were not observed in wild-type mice in our study and are also reported to be exceedingly rare in normal wild-type mice. ${ }^{58}$ Thus, these $\mathrm{Cdc73} 3^{+/-}$female mice provide a model to investigate the molecular basis of uterine tumourigenesis. A previous study of human uterine tumorigenesis has reported $>70 \%$ of Mullerian adenosarcomas to have: copy number gain for MYB protooncogene like 1 (MYBL1), mouse double minute 2 proto-oncogene (MDM2) and cyclin dependent kinase 4 (CDK4); copy number loss for cyclin dependent kinase inhibitor 2A (CDKN2A), breast cancer type 1 susceptibility protein (BRCA1)-associated protein 1 (BAP1) and $R B 1$; single nucleotide variations including nonsense mutations for TP53 and alpha thalassaemia/mental retardation syndrome X-linked (ATRX); and mutations in signalling pathways notably PI3K-AKT/PTEN. ${ }^{59}$ In addition, $>90 \%$ of leiomyomas (fibroids) have upregulation of G-protein coupled receptor 10 (GPR10) resulting in activation of the PI3K/AKT-mTOR pathway; ${ }^{54}$ while $70 \%$ of leiomyomas have a mutation of the mediator complex subunit (MED12) gene ${ }^{60}$ that encodes a scaffold protein which interacts with proteins that include $\beta$-catenin. It is interesting to note that parafibromin also directly interacts with $\beta$-catenin in the PAF complex to mediate Wnt signalling, ${ }^{24}$ whose dysregulation has been reported to be associated with development of intestinal and colon cancers, and it may be that similar pathways are involved in uterine tumourigenesis. ${ }^{61-63}$ Analysis of mouse embryonic fibroblasts from $C d c 73^{+/+}$and $C d c 73^{-/-}$mice revealed that the parafibromin/PAF complex regulated genes involved in cell growth and survival including the chromatin remodelling genes high mobility group AT-hook 1 (Hmga1) and 2 (Hmga2) to which parafibromin and PAF directly bind. ${ }^{19}$ Moreover, parafibromin may also act indirectly via HMGA1 which is a downstream mediator of aberrant Wnt signalling. ${ }^{64}$ Thus, loss of parafibromin expression in the mouse embryonic fibroblasts of $C d c 73^{-1-}$ mice has been reported to lead to downregulation of Hmga 1. ${ }^{19}$ However, this role of parafibromin in uterine tumourigenesis requires cautious extrapolation, as Hmga1 overexpression in transgenic female mice with 1-28 copies of Hmgala, is associated with development of uterine tumours resembling human uterine adenosarcomas. ${ }^{65,66}$ Finally, Wilms Tumour 1 protein (WT-1), which is often expressed in Mullerian adenosarcoma, has been reported to bind to the $C D C 73$ promoter and to repress $C D C 73$ expression in oral squamous cell carcinoma. ${ }^{67}$ The roles of these interactions of parafibromin in the aetiology of uterine tumourigenesis remain to be explored and our establishment of the $C d c 73^{+/-}$mice, which develop uterine tumours, will help to provide an important resource in these studies.

In summary, we have established a conventional $C d c 73^{+/-}$ mouse, in which males and females develop PAs and APAs, and females develop uterine tumours; thus this $\mathrm{Cdc} 73^{+/-}$mouse model is representative of the human HPT-JT syndrome. ${ }^{13-15}$ Moreover, we have developed parathyroid-specific Cdc73 knockout mouse models, which develop APAs and PAs. These mouse models will facilitate further in vivo investigations of the role of parafibromin in parathyroid and uterine tumourigenesis.

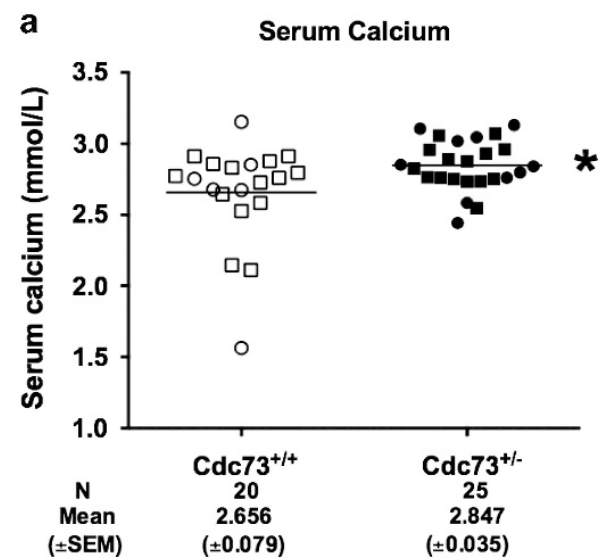

b

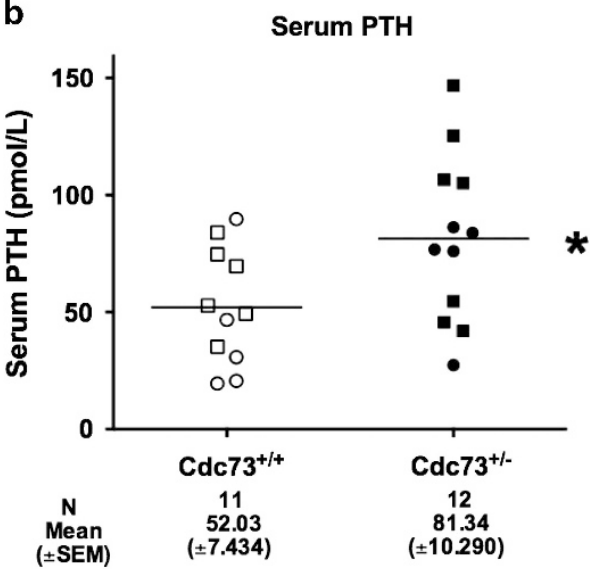

C



Figure 4. $\quad C d c 73^{+/-}$mice have increased mean serum calcium and PTH concentrations, when compared to $C d c 73^{+/+}$mice. (a) Serum calcium concentration, adjusted for albumin concentration, revealed an increased mean serum calcium concentration in $\mathrm{Cdc} 73^{+/-}$mice with parathyroid tumours when compared to $\mathrm{Cdc} 73^{+/+}$littermates with normal parathyroids ( $\left.{ }^{*} P<0.05\right)$. (b) Mean serum PTH concentration was elevated in $C d c 73^{+/-}$mice with parathyroid tumours compared to $C d c 73^{+/+}$littermates with normal parathyroids $\left({ }^{*} P<0.05\right)$. (c) Serum phosphate concentration in $C d c 73^{+/-}$mice with parathyroid tumours compared to $\mathrm{Cdc} 73^{+/+}$littermates with normal parathyroids. $\mathrm{Cdc} 73^{+/-}$mice with parathyroid tumours are shown as filled symbols and $C d c 73^{+/+}$littermates with normal parathyroids are shown as open symbols. Squares represent males and circles represent females. The age range of the mice was 17-24 months (mean \pm s.e.m. $=20.0 \pm 0.30$ ). Combined results from males and females for serum calcium, phosphate and PTH concentrations are shown, as there were no significant gender differences. Horizontal lines indicate mean values together with the standard error of the mean (s.e.m.), which is shown numerically below each group and the number $(N)$ of mice. 
$H \& E$
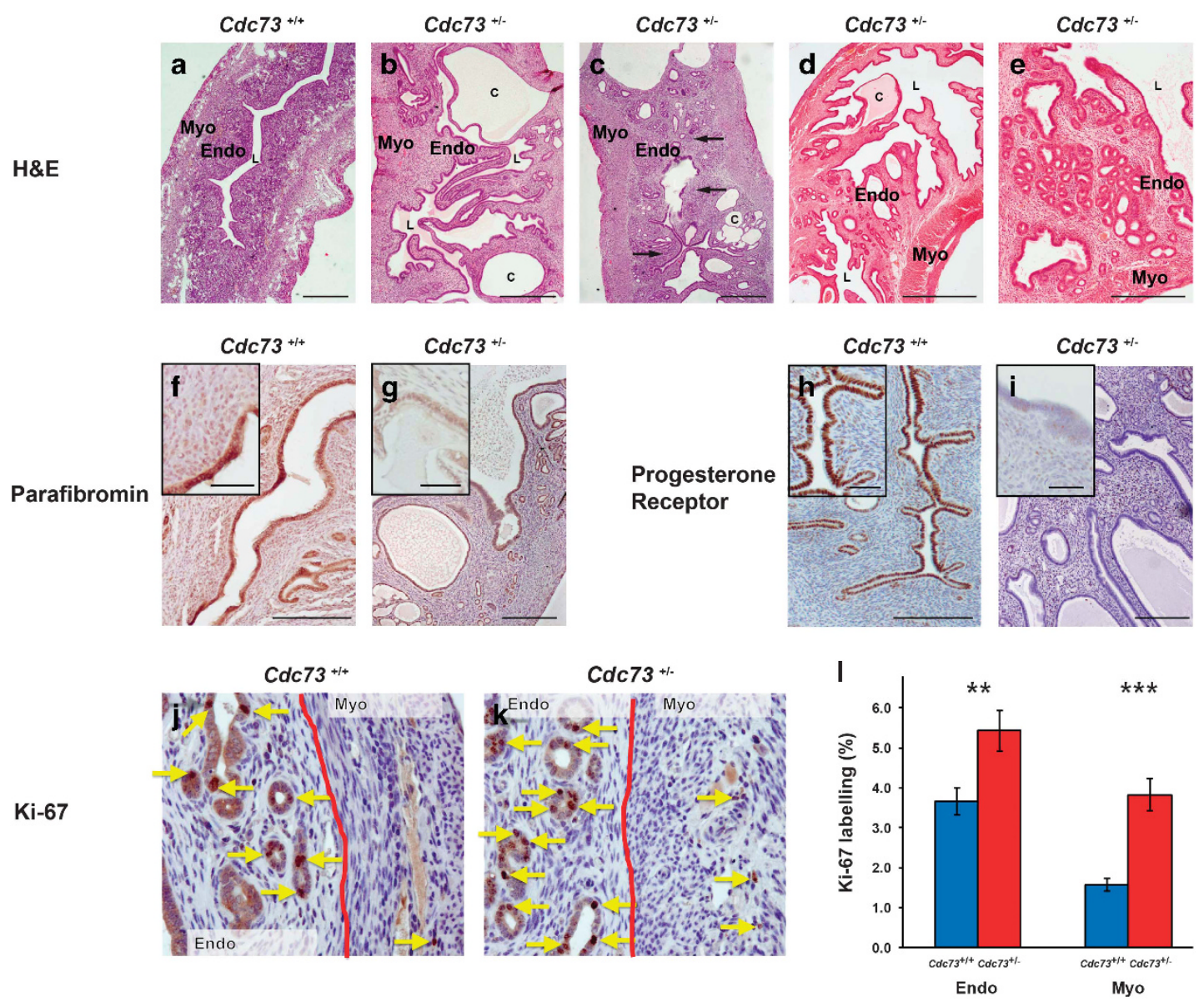

Figure 5. Uterine abnormalities develop in $C d c 73^{+/-}$mice. (a) H\&E-stained section of a uterus from a $C d c 73^{+/+}$mouse showing a normal myometrium (Myo), endometrium (Endo) and central lumen (I). (b, c) H\&E-stained sections of uteri from Cdc $73^{+/-}$mice with endometrial hyperplasia (b) and endometrial hyperplasia with squamous metaplasia (arrows) (c). Endometrial cysts (labelled c) and mucosal bridges traversing the lumen were observed in all the $\mathrm{Cdc} 3^{+/}$mice with neoplasms (b-e). (d) H\&E-stained section of a uterine adenofibroma from a $C d c 73^{+/-}$mouse with irregular polypoid endometrial projections into the lumen and cyst formation. (E) H\&E-stained section of a uterine adenomyoma with glandular endometrium and irregular endometrial polyps projecting into the lumen. (f) Immunostaining for parafibromin in a section of a uterus from a $C d c 73^{+/+}$mouse demonstrating normal endometrial expression of parafibromin. (g) Parafibromin-stained sections of a uterine tumour from a $\mathrm{Cdc}_{3} 3^{+/-}$mouse demonstrating reduced parafibromin expression in the endometrium. (h) Section of a uterus from a $\mathrm{Cdc} 73^{+/+}$mouse demonstrating normal expression of progesterone receptor in the endometrium. (i) Loss of endometrial progesterone receptor expression in a uterine tumour from a $C d c 73^{+/-}$mouse. (j) Immunostaining for the proliferation marker Ki-67 in a section of a uterus from a $C d c 73^{+/+}$mouse (brown nuclei, arrows) with haemotoxylin nuclear counterstain. The interface of endometrium (Endo) and myometrium (Myo) is indicated by a solid red line. (k) Increased nuclear Ki-67 expression was observed in the endometrium and myometrium of uteri from Cdc73 $3^{+/-}$mice with tumours (arrows). (I) Quantification of Ki-67 labelling index in the endometrium and myometrium of uteri from $C d c 73^{+/+}$mice (blue bars) and from $C d c 73^{+/-}$mice with tumours (red bars) demonstrated significantly higher proliferation in $C d c 73^{+/-}$mice $\left.{ }^{* *} P<0.01,{ }^{* * *} P<0.001\right)$ compared to $C d c 73^{+/+}$mice (total $(n=)$ fields of view from four mice per genotype for: $\mathrm{Cdc}^{+/+}$endometrium $n=79, \mathrm{Cdc73} 3^{+/}$endometrium $n=84, \mathrm{Cdc}^{+/+}$myometrium $n=78$, and Cdc73 $3^{+/-}$endometrium $n=82$ ). All scale bars represent $100 \mu \mathrm{m}$; insets have $400 \times$ magnification.

\section{MATERIALS AND METHODS}

\section{Mouse studies}

The generation of the conventional and conditional Cdc73 knockout mouse models has been previously described. ${ }^{19,68}$ Conventional $C d c 73^{+/-}$ mice established using the embryonic stem cell line RRE190, ${ }^{19}$ were maintained on a C57BL/6 background for 10 generations to obtain congenic $\mathrm{Cdc} 73^{+/-}$mice. $C d c 73^{L / L}$ mice ${ }^{19}$ were mated with parathyroidspecific Cre-expressing, PTH-Cre mice, ${ }^{24}$ to generate heterozygous $C d c 73^{+/ L} /$

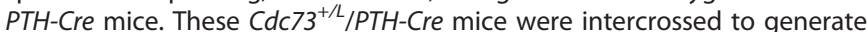
three genotypes expressing the Cre-recombinase: Cdc $73^{L / L} / P T H-C r e$, $\mathrm{Cdc} 73^{+/ L} / \mathrm{PTH}-\mathrm{Cre}$, and $\mathrm{Cdc} 73^{+/+} / \mathrm{PTH}-\mathrm{Cre}$. All mice were fed a standard diet (RM1 expanded diet, Special Diet Services Ltd., Witham, UK) and kept in accordance with national welfare guidelines and project license restrictions. Specifically, the animal studies were approved by the University of Oxford Ethical Review Committee and were licenced under the Animal (Scientific Procedures) Act 1986, issued by the United Kingdon Home
Office Department (PLL 30/2914), and the Instituitional Animal Care and Use Committee of the Van Andel Research Institute.

$\mathrm{Cdc} 3^{+/+}$and $\mathrm{Cdc73} 3^{+/-}$mice underwent a full post mortem at $\sim 7$ and $>17-21$ months of age, together with collection of blood samples for serum analysis and collecting of tissues for histological analysis. $C d c 73^{+/+} /$

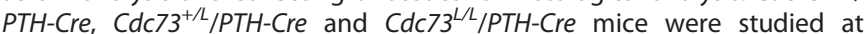
7-12 months and $\sim 20$ months of age. Macroscopic and microscopic examinations for HPT-JT associated tumours was undertaken.

\section{Genotype studies}

Genotypes of the $C d c 73^{+/+}$and $C d c 73^{+/-}$mice were determined by polymerase chain reaction $(P C R)$ analysis of DNA using $P C R$ primers (f $5^{\prime}$-GTCACAAA ACCAAAGCCTCTGGAACG-3', r $5^{\prime}$-GTTACAAGGTCATGG ATATTTCCACC-3' and Geor 5'-CTGCAAGGCGATTAAGTTGGGTAACG-3') to yield a wild-type band of $321 \mathrm{bp}$ and a mutant band of $289 \mathrm{bp}$. Reverse transcriptase-PCR (RT-PCR), using total RNA extracted from $C d c 73^{+/+}$and 
$\mathrm{Cdc} 73^{+/-}$kidneys was performed using either $C d c 73$-specific primers $3 \mathrm{f}$ (5'-GACCCGACCGAAAAGATCTAC- $3^{\prime}$ ), 9r (5'-AGGCTGTTTTGTACGCAATGT-3'), and rev (5'-CCCAACAGTTGCGCAGCCTG AAT-3') to yield a wild-type band of $593 \mathrm{bp}$, or a mutant band of $500 \mathrm{bp}$, (Figure 1b), as described. ${ }^{69}$ Genotypes of $\mathrm{Cdc} 73^{L / L} / \mathrm{PTH}-\mathrm{Cre}, \mathrm{Cdc7} 3^{+/ L} / \mathrm{PTH}-\mathrm{Cre}$, and $\mathrm{Cdc} 73^{+/+} / \mathrm{PTH}$-Cre mice were determined by PCR analysis of DNA using primers to detect the presence of LoxP and Cre-recombinase sites as previously described. ${ }^{19,24}$

\section{Western blot analysis}

Western blot analysis using total protein extracted from tissues of $\mathrm{Cdc} 73^{+/+}$ and $\mathrm{Cdc} 73^{+--}$mice was performed (Figure 1c), as previously described. ${ }^{69}$ The ability of the anti-parafibromin antibody to detect parafibromin was validated using siRNA targeting CDC73 (Dharmacon, Amersham, UK).

\section{Histology and immunohistochemistry}

Tissues were fixed overnight in neutral buffered 4\% paraformaldehyde before embedding and sectioning for immunohistochemical analysis. Haematoxylin and eosin staining was performed, using previously described methods. ${ }^{70}$ Commercially available antibodies were obtained and used according to the manufacturer's instructions (rabbit antiparafibromin A300-171A and anti-parafibromin IHC-00379 (Bethyl, Montgomery, TX, USA), rabbit anti-galectin-3 ab53082 (Abcam, Cambridge, UK), rat anti-Ki-67 M7249 (Dako, Glostrup, Denmark), rabbit anti-cyclin D1 clone SP4 (Thermo, Waltham, MA, USA), and rabbit anti-retinoblastoma sc7905 (Santa Cruz, Heidelberg, Germany)). Colour reaction was developed using secondary goat anti-rabbit antibody conjugated with horseradish peroxidase (HRP) (Dako, Glostrup, Denmark) or biotinylated rabbit anti-rat antibody and streptavidin/HRP (DakoCytomation, Glostrup, Denmark) and 3,3'-diaminobenzidine chromogen (DAB) solution (Vectashield, Peterborough, UK), and nuclei were counterstained with haematoxylin, as previously described. ${ }^{70}$ Masson's trichrome staining was used to assess for collagen in parathyroid tissue, such that collagen fibres were stained blue, nuclei were stained black and muscle, cytoplasm or keratin background was stained red/purple. Proliferation analysis was performed, as described, ${ }^{31}$ using continuous long-term administration of $1 \mathrm{mg} / \mathrm{ml}$ BrdU in drinking water, which specifically incorporates into the DNA of dividing cells, and $\mathrm{BrdU}$ was visualized utilizing commercially available antibodies (sheep anti-BrdU ab2285 (Abcam), Cy3-conjugated donkey antisheep (Jackson, West Grove, PA, USA)), as previously reported. ${ }^{31}$ The proportion of BrdU and Ki-67 containing nuclei was calculated from a minimum of six slides per specimen and four animals per group. Daily proliferation rates were expressed as the percentage of BrdU-containing nuclei divided by the number of days of BrdU exposure, as described. ${ }^{31}$ The Ki-67 proliferation index was calculated by dividing the number of Ki- 67 labelled nuclei by the total number of nuclei, multiplied by 100 , in randomly selected fields of view (200x magnification). ApopTag in situ apoptosis detection kit S7110 (Millipore, Billerica, MA, USA) was used according to manufacturer's instructions to assess for apoptotic cells utilizing terminal deoxynucleotidyl transferase (TdT) for detection of free $3^{\prime} \mathrm{OH}$ DNA termini formed by DNA fragmentation, as described. ${ }^{31}$

Established criteria from the World Health Organization and other reports, ${ }^{71-73}$ were used to distinguish between PCs, APAs and PAs. Histologically, the diagnosis of PC requires demonstration of either capsular, vascular, and/or perineural tumour invasion, tumour growth into adjacent tissues, lymph node metastasis, local recurrence or distant metastasis, while APAs have features of PCs that lack unequivocal evidence for invasive growth. ${ }^{71,74}$ Moreover, the presence of $\geqslant 4$ associated features of malignancy that include: capsular invasion without extension to surrounding soft tissue; mitosis $>5 / 10$ high power fields; broad intratumoural fibrous bands; coagulative tumour necrosis; diffuse sheetlike monotonous small cells with high nucleus:cytoplasmic ratio; diffuse cellular atypia; and presence of macronuclei in many tumour cells, qualifies for a diagnosis of $P C$, whereas the presence of only $1-3$ of these features, qualifies for a diagnosis of APA. ${ }^{71-73}$ PAs, which are benign neoplasms, do not have any of the features and also do not have evidence of invasive growth.

\section{Clinical chemistry}

Serum was analysed for calcium, phosphate, creatinine and albumin, as previously described. ${ }^{50}$ Total serum calcium $\left(\mathrm{Ca}^{2+}\right)$ was adjusted $(\mathrm{ACa})$ for albumin (Alb) using the formula: $\mathrm{ACa}=\mathrm{Ca}^{2+}(\mathrm{mmol} / \mathrm{l})-((\mathrm{Alb}$ $(\mathrm{g} / \mathrm{l})-30) \times 0.017)$, as described. ${ }^{50}$ Serum PTH was assayed using a commercial ELISA kit. $^{50}$ Conversion to yield SI units was as follows:
$\mathrm{Ca}^{2+}(\mathrm{mmol} / \mathrm{l})=($ serum calcium in $\mathrm{mg} / \mathrm{dl}) \times 0.2495$ and $\mathrm{PO}^{2-}(\mathrm{mmol} /$ I) $=($ serum phosphate in $\mathrm{mg} / \mathrm{dl}) \times 0.3229$.

\section{Statistical analysis}

Normally distributed data were analysed by Student's $t$-test or ANOVA followed by Tukey's multiple comparison post-hoc test. A two-tailed Fisher's exact test was used for $2 \times 2$ contingency tables, and Kaplan-Meyer analysis was performed using a two-tailed Log-rank test. ${ }^{50} P$-values $<0.05$ were considered statistically significant. Sample sizes are stated in the results section and the figure legends. The sample size for the survival study was selected based on a power of $80 \%$ to detect a $5 \%$ significance level (two-tailed) using equal numbers per group and a hazard ratio of 0.5; no animals were excluded, randomization was not required and blinding was not performed.

\section{CONFLICT OF INTEREST}

The authors declare no conflict of interest.

\section{ACKNOWLEDGEMENTS}

This work was supported by the Medical Research Council (MRC), UK (grant number G9825289/2004 and G1000467/2010), (GV Walls, M Stevenson, KE Lines, MR Bowl, J Jeyabalan, PJ Newey, AAC Reed, B Harding, KJ Bradley and RV Thakker), and the Van Andel Foundation, Grand Rapids, USA (P Wang, J Chen, BO Williams, BT Teh). GV Walls, PJ Newey and KJ Bradley received MRC Clinical Research Training Fellowships. This work was supported by grants from the United Kingdom Medical Research Council (MRC) (G9825289 and G1000467) to GVW, MS, KEL, PJN, AACR, MRB, $\mathrm{JJ}, \mathrm{BH}, \mathrm{KJB}$, and RVT; and the Van Andel Foundation, Grand Rapids, USA to JC, PW, $\mathrm{BOW}$ and $\mathrm{BTT}$.

\section{REFERENCES}

1 Carpten JD, Robbins CM, Villablanca A, Forsberg L, Presciuttini S, Bailey-Wilson J et al. HRPT2, encoding parafibromin, is mutated in hyperparathyroidism-jaw tumor syndrome. Nat Genet 2002; 32: 676-680.

2 Newey PJ, Bowl MR, Cranston T, Thakker RV. Cell division cycle protein 73 homolog (CDC73) mutations in the hyperparathyroidism-jaw tumor syndrome (HPT-JT) and parathyroid tumors. Hum Mutat 2010; 31: 295-307.

3 Cetani F, Pardi E, Marcocci C. Update on parathyroid carcinoma. J Endocrinol Invest 2016; 39: 595-606.

4 Szabo J, Heath B, Hill VM, Jackson CE, Zarbo RJ, Mallette LE et al. Hereditary hyperparathyroidism-jaw tumor syndrome: the endocrine tumor gene HRPT2 maps to chromosome 1q21-q31. Am J Hum Genet 1995; 56: 944-950.

5 Teh BT, Farnebo F, Kristoffersson U, Sundelin B, Cardinal J, Axelson R et al. Autosomal dominant primary hyperparathyroidism and jaw tumor syndrome associated with renal hamartomas and cystic kidney disease: linkage to 1q21-q32 and loss of the wild type allele in renal hamartomas. J Clin Endocrinol Metab 1996; 81: 4204-4211.

6 Shattuck TM, Valimaki S, Obara T, Gaz RD, Clark OH, Shoback D et al. Somatic and germ-line mutations of the HRPT2 gene in sporadic parathyroid carcinoma. N Engl J Med 2003; 349: 1722-1729.

7 Bradley KJ, Hobbs MR, Buley ID, Carpten JD, Cavaco BM, Fares JE et al. Uterine tumours are a phenotypic manifestation of the hyperparathyroidism-jaw tumour syndrome. J Intern Med 2005; 257: 18-26.

8 Haven CJ, Wong FK, van Dam EW, van der Juijt R, van Asperen C, Jansen J et al. A genotypic and histopathological study of a large Dutch kindred with hyperparathyroidism-jaw tumor syndrome. J Clin Endocrinol Metab 2000; 85: 1449-1454.

9 Bricaire L, Odou MF, Cardot-Bauters C, Delemer B, North MO, Salenave S et al. Frequent large germline HRPT2 deletions in a French National cohort of patients with primary hyperparathyroidism. J Clin Endocrinol Metab 2013; 98: E403-E408.

10 Knudson AG. Mutation and cancer: statistical study of retinoblastoma. Proc Natl Acad Sci USA 1971; 68: 820-823.

11 Juhlin CC, Haglund F, Obara T, Arnold A, Larsson C, Höög A. Absence of nucleolar parafibromin immunoreactivity in subsets of parathyroid malignant tumours. Virchows Arch 2011; 459: 47-53.

12 Witteveen JE, Hamdy NA, Dekkers OM, Kievit J, van Wezel T, Teh BT et al. Downregulation of CASR expression and global loss of parafibromin staining are strong negative determinants of prognosis in parathyroid carcinoma. Mod Pathol 2011; 24: 688-697.

13 Yart A, Gstaiger M, Wirbelauer C, Pecnik M, Anastasiou D, Hess D et al. The HRPT2 tumor suppressor gene product parafibromin associates with human PAF1 and RNA polymerase II. Mol Cell Biol 2005; 25: 5052-5060. 
14 Amrich CG, Davis CP, Rogal WP, Shirra MK, Heroux A, Gardner RG et al. Cdc73 subunit of Paf1 complex contains C-terminal Ras-like domain that promotes association of Paf1 complex with chromatin. J Biol Chem 2012; 287: 10863-10875.

15 Farber LJ, Kort EJ, Wang P, Chen J, Teh BT. The tumor suppressor parafibromin is required for posttranscriptional processing of histone mRNA. Mol Carcinog 2010; 49: 215-223.

16 Rozenblatt-Rosen O, Hughes CM, Nannepaga SJ, Shanmugam KS, Copeland TD Guszczynski T et al. The parafibromin tumor suppressor protein is part of a human Paf1 complex. Mol Cell Biol 2005; 25: 612-620.

17 Mosimann C, Hausmann G, Basler K. Parafibromin/Hyrax activates Wnt/Wg target gene transcription by direct association with beta-catenin/Armadillo. Cell 2006; 125: 327-341.

18 Mosimann C, Hausmann G, Basler K. The role of Parafibromin/Hyrax as a nuclear Gli/Ci-interacting protein in Hedgehog target gene control. Mech Dev 2009; 126: 394-405.

19 Wang P, Bowl MR, Bender S, Peng J, Farber L, Chen J et al. Parafibromin, a component of the human PAF complex, regulates growth factors and is required for embryonic development and survival in adult mice. Mol Cell Biol 2008; 28: 2930-2940.

20 Zhang C, Kong D, Tan MH, Pappas Jr DL, Wang PF, Chen J et al. Parafibromin inhibits cancer cell growth and causes G1 phase arrest. Biochem Biophys Res Commun 2006; 350: 17-24.

21 Woodard GE, Lin L, Zhang JH, Agarwal SK, Marx SJ, Simonds WF. Parafibromin, product of the hyperparathyroidism-jaw tumor syndrome gene HRPT2, regulates cyclin D1/PRAD1 expression. Oncogene 2005; 24: 1272-1276.

22 Stryke D, Kawamoto M, Huang CC, Johns SJ, King LA, Harper CA et al. BayGenomics: a resource of insertional mutations in mouse embryonic stem cells. Nucleic Acids Res 2003; 31: 278-281.

23 Turturro A, Witt WW, Lewis S, Hass BS, Lipman RD, Hart RW. Growth curves and survival characteristics of the animals used in the biomarkers of aging program. J Gerontol a-Biol 1999; 54: B492-B501.

24 Libutti SK, Crabtree JS, Lorang D, Burns AL, Mazzanti C, Hewitt SM et al. Parathyroid gland-specific deletion of the mouse Men1 gene results in parathyroid neoplasia and hypercalcemic hyperparathyroidism. Cancer Res 2003; 63: 8022-8028.

25 Duan K, Hernandez KG, Mete O. Clinicopathological correlates of hyperparathyroidism. J Clin Pathol 2015; 68: 771-787.

26 Yang RY, Rabinovich GA, Liu FT. Galectins: structure, function and therapeutic potential. Expert Rev Mol Med 2008; 10: e17.

27 Liu FT, Rabinovich GA. Galectins as modulators of tumour progression. Nat Rev Cancer 2005; 5: 29-41.

28 Bergero N, De Pompa R, Sacerdote C, Gasparri G, Volante M, Bussolati G et al. Galectin-3 expression in parathyroid carcinoma: immunohistochemical study of 26 cases. Hum Pathol 2005; 36: 908-914.

29 Saggiorato E, Bergero N, Volante M, Bacillo E, Rosas R, Gasparri G et al. Galectin-3 and Ki-67 expression in multiglandular parathyrold lesions. Am J Clin Pathol 2006; 126: 59-66.

30 Vasef MA, Brynes RK, Sturm M, Bromley C, Robinson RA. Expression of cyclin D1 in parathyroid carcinomas, adenomas, and hyperplasias: a paraffin immunohistochemical study. Modern Pathol 1999; 12: 412-416.

31 Walls GV, Reed AA, Jeyabalan J, Javid M, Hill NR, Harding B et al. Proliferation rates of multiple endocrine neoplasia type 1 (MEN1)-associated tumors. Endocrinology 2012; 153: 5167-5179.

32 Kumar NS, Richer J, Owen G, Litman E, Horwitz KB, Leslie KK. Selective downregulation of progesterone receptor isoform $B$ in poorly differentiated human endometrial cancer cells: implications for unopposed estrogen action. Cancer Res 1998; 58: 1860-1865.

33 Fukuda K, Mori M, Uchiyama M, Iwai K, Iwasaka T, Sugimori H. Prognostic significance of progesterone receptor immunohistochemistry in endometrial carcinoma. Gynecol Oncol 1998; 69: 220-225.

34 Fujimoto J, Ichigo S, Hori M, Nishigaki M, Tamaya T. Expression of ProgesteroneReceptor Form-a and Form-B Messenger-Rnas in Gynecologic Malignant-Tumors. Tumor Biol 1995; 16: 254-260.

35 Arnett-Mansfield RL, deFazio A, Wain GV, Jaworski RC, Byth K, Mote PA et al. Relative expression of progesterone receptors $A$ and $B$ in endometrioid cancers of the endometrium. Cancer Res 2001; 61: 4576-4582.

36 Gill AJ, Clarkson A, Gimm O, Keil J, Dralle H, Howell VM et al. Loss of nuclear expression of parafibromin distinguishes parathyroid carcinomas and hyperparathyroidism-jaw tumor (HPT-JT) syndrome-related adenomas from sporadic parathyroid adenomas and hyperplasias. Am J Surg Pathol 2006; 30: 1140-1149.

37 Holzenberger M, Dupont J, Ducos B, Leneuve P, Geloen A, Even PC et al. IGF-1 receptor regulates lifespan and resistance to oxidative stress in mice. Nature 2003; 421: 182-187.
38 Bokov AF, Garg N, Ikeno Y, Thakur S, Musi N, DeFronzo RA et al. Does reduced IGF-1R signaling in $\operatorname{lgf} 1 \mathrm{r}(+/-)$ mice alter aging? PLoS One 2011; 6: e26891.

39 Givi B, Shah JP. Parathyroid carcinoma. Clin Oncol 2010; 22: 498-507.

40 Gill AJ. Understanding the genetic basis of parathyroid carcinoma. Endocr Pathol 2014; 25: 30-34.

41 Kruijff S, Sidhu SB, Sywak MS, Gill AJ, Delbridge LW. Negative parafibromin staining predicts malignant behavior in atypical parathyroid adenomas. Ann Surg Oncol 2014; 21: 426-433.

42 Yu W, McPherson JR, Stevenson M, van Eijk R, Heng HL, Newey $\mathrm{P}$ et al. Whole-exome sequencing studies of parathyroid carcinomas reveal novel PRUNE2 mutations, distinctive mutational spectra related to APOBEC-catalyzed DNA mutagenesis and mutational enrichment in kinases associated with cell migration and invasion. J Clin Endocrinol Metab 2015; 100: E360-E364.

43 Juodele L, Serapinas D, Sabaliauskas G, Krasauskiene A, Krasauskas V, Verkauskiene $\mathrm{R}$ et al. Carcinoma of two parathyroid glands caused by a novel MEN1 gene mutation - a rare feature of the MEN 1 syndrome. Medicina (Kaunas) 2011; 47: 635-639.

44 Sato M, Miyauchi A, Namihira H, Bhuiyan MMR, Imachi H, Murao K et al. A newly recognized germline mutation of MEN1 gene identified in a patient with parathyroid adenoma and carcinoma. Endocrine 2000; 12: 223-226.

45 Jenkins PJ, Satta MA, Simmgen M, Drake WM, Williamson C, Lowe DG et al. Metastatic parathyroid carcinoma in the MEN2A syndrome. Clin Endocrinol 1997; 47: 747-751.

46 Cryns VL, Thor A, Xu HJ, Hu SX, Wierman ME, Vickery AL et al. Loss of the retinoblastoma tumor-suppressor gene in parathyroid carcinoma. $N$ Engl J Med 1994; 330: 757-761.

47 Juhlin CC, Haglund F, Villablanca A, Forsberg L, Sandelin K, Branstrom R et al. Loss of expression for the Wnt pathway components adenomatous polyposis coli and glycogen synthase kinase 3-beta in parathyroid carcinomas. Int J Oncol 2009; 34: 481-492.

48 Cryns VL, Rubio MP, Thor AD, Louis DN, Arnold A. P53 abnormalities in human parathyroid carcinoma. J Clin Endocr Metab 1994; 78: 1320-1324.

49 Svedlund J, Barazeghi E, Stalberg P, Hellman P, Akerstrom G, Bjorklund P et al. The histone methyltransferase $\mathrm{EZH} 2$, an oncogene common to benign and malignant parathyroid tumors. Endocr Relat Cancer 2014; 21: 231-239.

50 Harding B, Lemos MC, Reed AAC, Walls GV, Jeyabalan J, Bowl MR et al Multiple endocrine neoplasia type 1 knockout mice develop parathyroid, pancreatic, pituitary and adrenal tumours with hypercalcaemia, hypophosphataemia and hypercorticosteronaemia. Endocr Relat Cancer 2009; 16: 1313-1327.

51 Imanishi Y, Hosokawa Y, Yoshimoto K, Schipani E, Mallya S, Papanikolaou A et al. Primary hyperparathyroidism caused by parathyroid-targeted overexpression of cyclin D1 in transgenic mice. J Clin Invest 2001; 107: 1093-1102.

52 Loffler KA, Biondi CA, Gartside MG, Serewko-Auret MM, Duncan R, Tonks ID et al. Lack of augmentation of tumor spectrum or severity in dual heterozygous Men1 and Rb1 knockout mice. Oncogene 2007; 26: 4009-4017.

53 Evans P, Brunsell S. Uterine fibroid tumors: diagnosis and treatment. Am Fam Physician 2007; 75: 1503-1508.

54 Varghese BV, Koohestani F, McWilliams M, Colvin A, Gunewardena S, Kinsey WH et al. Loss of the repressor REST in uterine fibroids promotes aberrant $\mathrm{G}$ proteincoupled receptor 10 expression and activates mammalian target of rapamycin pathway. Proc Natl Acad Sci USA 2013; 110: 2187-2192.

55 Hayes MP, Ellenson LH. Molecular alterations in uterine serous carcinoma. Gynecol Oncol 2010; 116: 286-289.

56 Commandeur AE, Styer AK, Teixeira JM. Epidemiological and genetic clues for molecular mechanisms involved in uterine leiomyoma development and growth. Hum Reprod Update 2015; 21: 593-615.

57 Parker WH. Etiology, symptomatology, and diagnosis of uterine myomas. Fertil Steril 2007; 87: 725-736.

58 Reuber MD, Vlahakis G, Heston WE. Spontaneous hyperplastic and neoplastic lesions of the uterus in mice. J Gerontol 1981; 36: 663-673.

59 Howitt BE, Sholl LM, Cin PD, Jia YH, Yuan LP, MacConaill L et al. Targeted genomic analysis of Mullerian adenosarcoma. J Pathol 2015; 235: 37-49.

60 Makinen N, Mehine M, Tolvanen J, Kaasinen E, Li YL, Lehtonen HJ et al. MED12, the Mediator Complex Subunit 12 Gene, Is Mutated at High Frequency in Uterine Leiomyomas. Science 2011; 334: 252-255.

61 Morin PJ, Sparks AB, Korinek V, Barker N, Clevers H, Vogelstein B et al. Activation of beta-catenin-Tcf signaling in colon cancer by mutations in beta-catenin or APC. Science 1997; 275: 1787-1790.

62 Korinek V, Barker N, Morin PJ, vanWichen D, deWeger R, Kinzler KW et al. Constitutive transcriptional activation by a beta-catenin-Tcf complex in APC(-/-) colon carcinoma. Science 1997; 275: 1784-1787.

63 Myant K, Sansom OJ. Wnt/Myc interactions in intestinal cancer: Partners in crime. Exp Cell Res 2011; 317: 2725-2731. 
64 Bush BM, Brock AT, Deng JYA, Nelson RA, Sumter TF. The Wnt/beta-catenin/T-cell factor 4 pathway up-regulates high-mobility group $A 1$ expression in colon cancer. Cell Biochem Funct 2013; 31: 228-236.

$65 \mathrm{Xu}$ Y, Sumter TF, Bhattacharya R, Tesfaye A, Fuchs EJ, Wood LJ et al. The HMG-I oncogene causes highly penetrant, aggressive lymphoid malignancy in transgenic mice and is overexpressed in human leukemia. Cancer Res 2004; 64: 3371-3375.

66 Tesfaye A, Di Cello F, Hillion J, Ronnett BM, Elbahloul O, Ashfaq R et al. The highmobility group A1 gene up-regulates cyclooxygenase 2 expression in uterine tumorigenesis. Cancer Res 2007; 67: 3998-4004.

67 Rather MI, Swamy S, Gopinath KS, Kumar A. Transcriptional Repression of Tumor Suppressor CDC73, Encoding an RNA Polymerase II Interactor, by Wilms Tumor 1 Protein (WT1) Promotes Cell Proliferation IMPLICATION FOR CANCER THERAPEUTICS. J Biol Chem 2014; 289: 968-976.

68 Piret SE, Thakker RV. Mouse models for inherited endocrine and metabolic disorders. J Endocrinol 2011; 211: 211-230.

69 Nesbit MA, Bowl MR, Harding B, Ali A, Ayala A, Crowe C et al. Characterization of GATA3 mutations in the hypoparathyroidism, deafness, and renal dysplasia (HDR) syndrome. J Biol Chem 2004; 279: 22624-22634.

70 Grigorieva IV, Mirczuk S, Gaynor KU, Nesbit MA, Grigorieva EF, Wei QZ et al. Gata3-deficient mice develop parathyroid abnormalities due to dysregulation of the parathyroid-specific transcription factor Gcm2. J Clin Invest 2010; 120: 2144-2155.

71 DeLellis RA, International agency for research on cancer, World Health Organization, International Academy of Pathology, International Association for the
Study of Lung Cancer. Pathology and Genetics of Tumours of Endocrine Organs, Third edn vol. 8. IARC Press: Lyon, France, 2004.

72 Kumari N, Chaudhary N, Pradhan R, Agarwal A, Krishnani N. Role of Histological Criteria and Immunohistochemical Markers in Predicting Risk of Malignancy in Parathyroid Neoplasms. Endocr Pathol 2016; 27: 87-96.

73 Chan JKC. Tumors of thyroid and parathyroid glands. In: Fletcher CDM (ed). .Diagnostic Histopathology of Tumors, vol. 2. Elsevier Saunders: China, 2013; pp 1273-1293.

74 DeLellis RA. Parathyroid tumors and related disorders. Modern Pathol 2011; 24: S78-S93.

75 Ensembl. ENSMUSG00000026361. Available at: www.ensembl.org/Mus_musculus/ Gene/Summary?db=core;g=ENSUMG00000026361; $r=1: 143598800-143702893$. Mouse GRCm38.p5.

This work is licensed under a Creative Commons Attribution 4.0 International License. The images or other third party material in this article are included in the article's Creative Commons license, unless indicated otherwise in the credit line; if the material is not included under the Creative Commons license, users will need to obtain permission from the license holder to reproduce the material. To view a copy of this license, visit http://creativecommons.org/licenses/ by/4.0/

(c) The Author(s) 2017

Supplementary Information accompanies this paper on the Oncogene website (http://www.nature.com/onc) 